\title{
ZERO WASTE + SUSTAINABLE ARCHITECTURE = RENEWABLE ENERGY
}

\author{
Márcia Macul \\ Sérgio Prado \\ Kláudio Cóffani Nunes \\ Curadores da Terra, \\ Brazil
}

\section{INTRODUCTION}

A new continuous cycle of co-creation of Sustainable Green Municipalities (PPP)

extending the 3 scales of Space / Time:

the hands of the (individual) + the body (group) $=$ a town (ambient)

Continuous Cycle CO-CREATION = PLANET ORGANIFICATION

Dematerializing / Rematerializing several kinds of waste means "organifying them," redefining new levels of strength and durability, giving value to their use in the municipalities where they are produced thereby resolving the major questions of the current National Policy of Solid Waste / Reverse Responsibility Law 12,305, which is being implemented in August 2014. This cyclical production chain can be certified with a municipal Global Green Seal, creating an effective \& pragmatic Bio-Economy to communities and operate as a full "CRE" program (Cleaning + Educating = Reconstructing), generating a "LEI" (Labor + Employment = Income). This direct systemic model - from "CONSUMPTION" toward a "SUM OPTION" - using a quickly adaptable sediment-wide network of Micro / Macro Organic Credit - uniting various types of dry wastes that are fragmented with a Vegetable Polyurethane originating from castor oil plants and other techniques, in a co-creation of multi-material BUILDING SUSTAINABILITY. Micro and macro organic particles "bind" minerals "hardening" them, and plastics giving "flexibility" to the set, canceling all entropies; the organic seals the rays of the sun protecting plastics, which keep the minerals dry.

The unification of the three fundamental components (plastics + organics + minerals) create new hardness (space), durability (time) and do not fracture (or leak) thus serving as a new media for the INCREASED PRODUCTION of GREEN AREAS in all horizontal / vertical contexts - ORGANIFICATION - creating better thermal / acoustics, lower power consumption, better nutrition (green roofs) and clearing the air and the whole environment favoring the receipt of Carbon Credits.

This synthesis works in continuity and acts as a true "YES THESIS": ZERO WASTE + SUSTAINABLE ARCHITECTURE $=$ RENEWABLE ENERGY as a model of a " $4^{\text {th }}$

https://doi.org/10.15626/Eco-Tech.2014.004 


\section{Linnaeus ECO-TECH '14 \\ Kalmar, Sweden, November 24-26, 2014}

Dimension Architecture". Since this whole cyclical process overcomes the current concepts of "fatigue of materials and expiring dates" that now exists, we implement a new "PRAGMATIC BIOECONOMY" establishing, redefining and ensuring: 1. Proven Source + 2. Clean Productivity $=3$. Correct Destination, as a fundamental definition of a Sustainable Green City.

The collective work in Eco-Sustainable Factories in different neighborhoods with the local population collecting and recycling waste with specific recommendations, allows the understanding and analysis of environmental issues faced and the classification of local resources that can be accessed to implement the principles of sustainable development, including the training of human resources consciousness as NEW SUSTAINABLE BUILDERS. The main focus of this portion of the project is to solve and address two of the most problematic issues that our country faces today - the accumulation of garbage and a shortage of housing for the less privileged, settled here as an unique synergistic solution.

Currently, we have formed a partnership with a group in Estonia that develops models of mobile equipment to sanitize all waste deposited in landfills and dumps, making it possible to restore

and restructure new sports and cultural centers for staff populations, as well as enabling new uses of the daily waste discards of the cities. At the end of 2013, this complete team (of 30 researchers, teachers, businessmen) came to Brazil, at our invitation, visiting landfills and dumps of Bauru and Ubatuba, as well as formalizing first agreements with UNESP, later to serve in both municipalities. In Sweden, we are collaborating with Professor William Hogland of the Linnaeus University regarding relocation and transformation of organic waste into bio-gas. Professor Hogland has met with multiple Petrobras teams involved in this matter. This project directly interests the major cities of the Northern Coast of São Paulo \& Southern Atlantic Coast of Rio de Janeiro.

Eco-Sustainable Eco Factories installed in several neighborhoods working with the local population re-collecting and recycling all wastes allows the understanding and analysis of environmental facilitating and the classification of local resources of the northern Coast of SP (Ubatuba + Caraguatatuba, Ilhabela, S.Sebastião) and the southern coast of RIO (Paraty \& Angra dos Reis, which together form the largest group of BRAZIL's ECO-TOURISM. All are surrounded by National and State Parks, both with Mata Atlantica Mountains and reaching the islands in the sea which are right in front of the Petrobras Pre-Salt. Many of them already hold shares of the profits of the pre-salt and this will facilitate a future investment of these resources into this complete educational system maintenance / cleaning MAN / NATURE, in conjunction with our current process (CO-CREATION). Processing waste into new constructive elements as a model able to be expanded throughout the country for use in creating vivid and compact units for Sustainable Green Vegetable Homes can meet the urgent requirement of nearly half the population who are in immediate need.

Our current work now is this co-creation of pooling Municipalities (Ubatuba and Agudos), the Brazilian national construction enterprise Camargo Correa Group and multinational environmental engineers Maccaferri Industrial Group, all aiming to deploy three ecotechnical prototypes (as a "DNA of Sustainability") in 3 scales, and the 3 specific construction exemplars: 


\section{Linnaeus ECO-TECH '14 \\ Kalmar, Sweden, November 24-26, 2014}

1 - Eco-Points - 10 to $20 \mathrm{~m} 2$ (Ubatumirim, Ubatuba, SP) - The Eco-Points have 3 diverse structures: a) structural rammed earth wall, b) pillar gabions with mineral debris from work and c) pillar plastics amalgamated in a plastic net sealing the mold. Every Model serves as a prototype for the other sustainable constructions that follows;

2 - Eco-Factories / Sustainable Community Centers - the basis for further 200m2 (Agudos and Ubatumirim, Ubatuba, SP)

3 - Sustainable Homes / Houses Vegetable-base - $50 \mathrm{~m} 2$ for more (Agudos and Ubatumirim, Ubatuba, SP)

These 3 scales buildings will be developed similar to the following systems:

Structures - foundation stone, freestanding walls of raw land (rammed earth), with remains of gabions and stone works (Maccaferri) columns packed with various locks and waste in closed molds.

Locks - blocks and bricks of land or waste and plastic and wire mesh (Maccaferri)

Flooring - plates made with waste (partnership with Gavassa, Ubatuba)

Penthouses - coated bamboo earth, lime, fiber and commingled waste plastics forming networks and suitable for plastic screens hanging gardens (Maccaferri).

Composting - organic waste / biogas (several partners)

The 3 scales we can attend are:

1. SUSTAINABLE ARCHITECTURE: The GREEN VEGETABLES HOMES with rooftop gardens that feed its users are constructive models of easy preparation and understanding, as an "Adult Lego Game”. The whole concept developed here approaches the notion of systemic health in housing - as a "mother cell". This construction begins with natural materials such as raw land (taipas) is a phenomenological synergy of great importance to all residents for the entire family - beginning with newborn infants. The land has a significant proximity to the human body, is the most abundant material in nature, plus it is very responsive and pleasant to the touch. It is the most inert material, covering the entire surface where your feet go. The freestanding walls, apiloadas with raw land give perfect thermal and acoustic comfort. Without the use of cement and iron it is extremely clean and healthy, and allows a pleasant interior microclimate in summer and winter, avoiding the use of parallel energy (heating, air conditioning). When demolished the "taipas" return to the soil, to be ground without creating debris.

The locks, blocks and floors are made with the reuse of waste. On the sides, a protective mesh surrounds the entire building and follows protecting mulch (bamboo / gardens / food). Here, something new takes shape a "quanta". A partnership with the international company Maccaferri, allows us to develop a new type of network made entirely with various waste plastics that otherwise end up forming the largest ocean trash. The refabricating of the waste plastics can be achieved with our Estonian partners who have developed light technological plastic tubes $(2 \mathrm{~m} \times 6 \mathrm{~m})$ for cleaning all different plastics residuals - amalgamating them as new grids, serving to cover vertically and horizontally the Sustainable Vegetable Homes. Again, these re-built grids of several plastic adhesions can create new networks replacing the 


\section{Linnaeus ECO-TECH '14 \\ Kalmar, Sweden, November 24-26, 2014}

traditional solid dividing walls between properties. Nothing else is tight; the networks are soft and grow all the vegetation growth to divide the houses. In the backyard is a compost box, integrated with a cleaning pond system and lakes creating fish. The waste of fish farming is the best organic food to the horizontal \& vegetable gardens via hydroponics. Greenery at home becomes a symbol of an appropriate urban agro-ecology. Recent partnerships have already emerged with some municipalities - Agudos and Ubatuba are the new players.

The Community Centre, built in a similar system will have classrooms used to empower communities to work and create new materials for SUSTAINABLE HOMES and GARDENS. This is an extremely attractive circular system, since every moment, in every season, is reinstating what is no longer useful (garbage / waste), recreating a new visual, sensory, professional productivity!

2. SUSTAINABLE ART- As an essential component in each project, we propose art installations, with an Eco-approach assigned to a work of art developed with the local community waste - acting as a cognitive visual sign of each local community as responsible.

3. SUSTAINABLE ENVIRONMENTS. - In each Sustainable Green City, Eco Sustainable Sanctuaries will be created - unifying neighboring areas of land owners interested in implementing crops needed such as bamboo for construction or oil seeds (plants that will be used for the production of vegetable polyurethane), and other organic quality products. All these can be planted in any environment (heat or cold) and are not monoculture; a new tripod for ART + ARCHITECTURE + SUSTAINABLE ENVIRONMENT. Cities are now the major driver of atmospheric warming (80\%) and Brazil already has overcrowding with $87 \%$ of the population into cities - so the Eco Factory and Eco Sustainable Sanctuaries, creating Sustainable Green Cities who reuse their own waste transforms into new "works without leftovers " These structures built with natural materials such as raw land and biodegradable vegetable polyurethane (to replace the use of concrete, iron, cement) aggregating rural and urban waste, will be the holders of financial resources from new or parallel institutions.

Today we, as the NGO VERDEVER / CURADORES DA TERRA, operate in two particular areas - Fazenda Velha (the Old Farm) Mantiqueira, Itamonte, MG. We began planting bamboos, growing berries and trout farming, with the goal of working with local communities and their crafts and wisdom. In the Sanctuary Aguazuis, Ubatuba, SP, we are developing an agro-forest, with native fruits of the region for local sustainability itself - bamboo, mahogany, cambuci, peach palm, palm juçara, etc. - lessons from their local communities. (images)

\section{Synthesis}

This broad objective trilogy Art + Architecture $=$ Sustainable Environment today is fundamentally qualified to become a significant and conscientious model for communities, spreading as sustainable rezones. This unifying view works to draft new Green Cities, Water and Sustainable Biomes - spreading the concepts in all urban counties, rural areas and facilitating the cleaning of rivers, seas and oceans - revolution in evolution of customs!

Nationally, all this work in recent decades has led to two bills - starting with the PL 269/99 (Senate) "Brazil Clean Waters" (which is incorporated by synthesizing the socioenvironmental core principles of current PNRS / RR / 12.305) and PL 1269/07 (ALESP) 


\section{Linnaeus ECO-TECH '14}

Kalmar, Sweden, November 24-26, 2014

"Zero Waste, Sustainable Architecture, Renewable Energy", approved by the seven (7) committees, having generated the new concept of BLUE GREEN CITIES by the State Ministry of the Environment of São Paulo, valid for all cities in the state of São Paulo.

Internationally, our "Trustees Project Earth" won in April 2011, the Competition SUSTAINABLE URBAN HOUSING, Foundations created by Ashoka / Changemakers \& Rockefeller Foundation and several U.S. departments, such as U.S. Department of State / HUD / EPA / USAID / AMERICAN PLANNING ASSOCIATION - proposed as ideal property to be replicated in all 32 countries of South and Central America, with the characteristics of reuse of all waste types and bearing walls of earth and stones.

Now, we have and can count on various interested cities, companies and builders with broad international reputation and we believe that the accomplishment of: 1 . The creation and construction of three first-units as symbols of this project (hardware) and, in parallel, 2. An educational program - with real 3D animations + images in three languages - Portuguese, Spanish and English (software) will make this project of global importance available and known to the world. 